PATIK : Jurnal Hukum

https://ejournal.uhn.ac.id/index.php/patik

Volume 09 Nomor 02, Agustus 2020 Page : 137 - 146

p-issn : $2086-4434$

\title{
PERTANGGUNGJAWABAN PIDANA TERHADAP PELAKU YANG MELAKUKAN PENGANGKUTAN BAHAN BAKAR MINYAK (BBM) TANPA IZIN USAHA PENGANGKUTAN (STUDI PUTUSAN NOMOR : 569/PID.SUS/2019/PN.MPW)
}

\author{
Martha Grace Hutapea, Kasman Siburian, Jusnizar Sinaga \\ Fakultas Hukum, Universitas HKBP Nommensen \\ kasmansiburian@uhn.ac.id
}

\begin{abstract}
Abstrak
Penelitian ini bertujuan untuk mengetahui penerapan ketentan pidana materil dan pidana formil terhadap Tindak Pidana Pengangkutan Bahan Bakar Minyak (BBM) Tanpa Izin Usaha Pengangkutan (Studi Putusan Nomor : 569/PID.SUS/2019/PN.MPW). Adapun yang menjadi permasalahan dalam penulisan ini adalah Bagaimana pertanggungjawaban pidana terhadap pelaku tindak pidana yang melakukan kegiatan usaha pengangkutan bahan bakar minyak tanpa izin usaha pengangkutan sehingga hakim menjatuhkan pidana. Data sekunder diperoleh melalui beberapa literature berupa buku-buku, jurnal hokum, dan pengaturan perundang-undangan. Metode penelitian hukum yang digunakan dalam penelitian ini adalah jenis penelitian hukum metode penelitian kualitatif, yaitu dengan cara meneliti bahan pustaka yang ada. Berdasarkan hasil penelitian yang dilakukan pada Putusan Nomor : 569/PID.SUS/2019/PN.MPW, maka dapat disimpulkan bahwa Penegakan Hukum Terhadap Pelaku Yang Melakukan Pengangkutan Bahan Bakar Minyak Tanpa Izin Usaha Pengangkutan di pidana penjara dengan pidana 3 (tiga) bulan penjara dan denda sebesar Rp. 1.000.000,00 (satu juta rupiah) yang apablia tidak dibayar oleh terdakwa maka diganti dengan kurungan selama 1 (satu) bulan kurungan.
\end{abstract}

Kata Kunci : Pertanggungjawaban, Pelaku Tindak Pidana, Tanpa Izin Usaha Pengangkutan Bahan Bakar Minyak.

\section{Abstract}

This study aims to determine the application of material and formal criminal provisions against the Crime of Transportation of Fuel (BBM) without a Transportation Business License (Decision Study Number: 569 / PID.SUS / 2019 / PN.MPW). As for the problem in this writing is how the criminal responsibility to the perpetrator of a criminal act who carries out the business of transporting fuel oil without a transportation business license so that the judge imposes a criminal offense. Secondary data is obtained through several literatures in the form of books, legal journals, and statutory regulations. The legal research method used in this research is a type of legal research, a qualitative research method, namely by examining existing library materials. Based on the results of research conducted on Decision Number: 569 / PID.SUS / 2019 / PN.MPW, it can be concluded that Law Enforcement Against Perpetrators Transporting Oil Fuel Without a Transportation Business License is imprisoned with 3 (three) months imprisonment. and a fine of Rp. 1,000,000.00 (one million rupiah), if the defendant does not pay it, he will be replaced with 1 (one) month of imprisonment.

Keywords: Accountability, Perpetrators of Crime, Without a Business Permit to Transport Fuel Oil. 


\section{PATIK : JURNAL HUKUM Vol : 09 No. 2, Agustus 2020, Hal 137 - 146}

\section{Pendahuluan}

Negara Republik Indonesia adalah sebuah Negara hukum. Dalam pembukaan Undang-Undang Dasar Negara Republik Indonesia Tahun 1945 pada Pasal 1 Ayat (3), mengatur bahwa "Indonesia adalah Negara hukum". Artinya, semua tindakan harus dilakukan berdasarkan hukum yang berlaku dan perbuatan tersebut dapat dipertanggungjawabkan pula. ${ }^{1}$ Hukum itu adalah aturan dan baru ada karena adanya masyarakat yang terorganisasikan, sehingga hukum itu adalah aturan yang dibuat oleh mereka yang memang ditugasi untuk membuatnya meskipun dalam bentuknya yang masih sederhana. $^{2}$ Tujuan hukum adalah untuk menciptakan keteraturan dan ketertiban dalam kehidupan bermasyarakat serta untuk mencegah orang bertindak sewenang-wenang terhadap orang lain. Konsep Negara hukum yang dianut Indonesia tidak dapat dipisahkan dari nilai-nilai moral pancasila. Artinya Pancasila sebagai roh dan negara sebagai badannya.Sebab pancasila merupakan filsafat bangsa Indonesia. Sejalan dengan perkembangan masyarakat modern, maka hukum juga turut mengalami perkembangan. Hukum pidana merupakan hukum yang mengatur tentang perbuatan-perbuatan apa yang dapat dihukum dan hukuman apa yang dapat dijatuhkan kepada si pelaku atas kejahatan atau pelanggaran yang telah dilakukannya. ${ }^{3}$ Nullum delictum nulla poena sine praevia lege poenali, artinya tiada suatu perbuatan yang dapat dihukum, kecuali atas kekuatan ketentuan pidana dalam undang-undang yang telah ada lebih dahulu daripada perbuatan itu. ${ }^{4}$ Hukumpidana bukan merupakan tujuan dalam dirinya sendiri namun memiliki fungsi pelayanan ataupun fungsi sosial. ${ }^{5}$

Minyak dan Gas Bumi merupakan sumber daya alam strategis serta memegang peranan yang sangat penting dalam perekonomian nasional Indonesia. Minyak dan gas bumi tersebut dikuasai oleh negara, hal ini telah dituangkan dalam Undang-Undang Dasar Tahun 1945 pada Pasal 33 ayat (3) yang berisi “ Bumi dan air serta kekayaan alam yang terkandung di dalamnya dikuasai oleh Negara dan dipergunakan untuk sebesar-besarnya kemakmuran rakyat". Artinya kuasa pertambangan tetap dipegang oleh pemerintah dengan maksud agar pemerintah dapat mengatur, memelihara, dan menggunakan kekayaan nasional tersebut bagi sebesar-besarnya kemakmuran rakyat.Pemerintah atas nama Negara menguasai semua hak yang terkandung dalam sumber daya migas.

Pengangkutan adalah kegiatan pemindahan minyak bumi, gas bumi, dan/atau hasil olahannya dari wilayah kerja atau dari tempat penampungan hasil pengolahan, termasuk pengangkutan gas bumi melalui pipa transmisi dan distribusi. Kegiatan usahapengangkutandan pendistribusian minyak dan gas bumi di lakukan oleh badan hukum Indonesia berbentuk perseoan terbatas, badan usaha milik daerah, atau koperasi yang didirikan khusus untuk perusahaan yang melakukan

kegiatanusaha pengangkutan dan pendistribusian minyak dan gas bumi, badan hukum yang bersangkuan tersebut wajib memiliki izin usaha yang diberikan selama perusahaan yang bersangkutan masih menjalankan kegiatan usahanya. ${ }^{6}$

${ }^{1}$ Simamora, Janpatar., Tafsir Makna Negara Hukum dalam Perspektif Undang-Undang Dasar Negara Republik Indonesia Tahun 1945, Jurnal Dinamika Hukum FH Universitas Jenderal Soedirman, Vol. 14 No. 3 September 2014, hlm. 547-561.

${ }^{2}$ Peter Mahmud Marzuki, 2008, Pengantar Ilmu Hukum, Jakarta, Prenada Media Group hlm. 41-43.

${ }^{3}$ Ojak Nainggolan, 2014, Pengantar Ilmu Hukum, Medan, UHN PRESS, hlm.105.

${ }^{4}$ Ibid, hlm. 83 .

${ }^{5}$ Barda Nawawi Arief, 2003, Kapita Selekta Hukum Pidana, Bandung,Citra Adytia Bakti, hlm. 1314.

\footnotetext{
${ }^{6}$ Abdulkadir Muhammad, 2008, Hukum Pengangkutan Niaga, Bandung,Citra Aditya Bakti hlm. 80.
} 


\section{PATIK : JURNAL HUKUM Vol : 09 No. 2, Agustus 2020, Hal 137 - 146}

Salah satu peraturan perundang-undangan yang mengatur tentang sanksi pidana di bidang minyak dan gas bumi yaitu Undang-undang Nomor 22 Tahun 2001 tentang Minyak dan Gas bumi. Undang-undang tersebut menyatakan bahwa yang menjadi substansi pokok adalah Minyak dan Gasa bumi merupakan salah satu sumber daya alam strategis yang terkandung di dalam wilayah hukum pertambangan di Indonesia dan merupakan kekayaan nasioanal yang di kuasai oleh negara serta penyelenggaraanya atau pelaksanaanya di lakukan oleh pemerintah.

Dalam ketentuan Pasal 55 Undang-Undang Nomor 22 Tahun 2001 tentang Minyak dan Gas bumi, perbuatan pengangkutan, pendistribusian, penampungan, penimbunan hingga penjualan bahan bakarminyak (BBM), menyebutkan bahwa:"Setiap orang yang menyalahgunakan pengangkutan dan/atau Niaga bahan bakar minyak yang di subsidi pemerintah dipidana dengan pidana penjara paling lama 6 (enam) tahun dan denda paling tinggi Rp.60.000.000.000,00 (enam puluh miliar rupiah)".

Dasar penegak hukum untuk melakukan suatu tindakan penegakan hukum adalah berdasarkan Undang-undang. Penanggulangan dari pihak penegak hukum yang salah satunya adalah pihak kepolisian bertujuan untuk mengendalikan dan mengawasi serta melakukan penangkapan terhadap seseorang atau badan hukum yang melakukan kejahatan tersebut. Apabila Undang-undang tidak memberikan suatu defenisi yang jelas maka akan banyak sekali penafsiran yang dapat digunakan dan akan menimbulkan ketidakpastian hukum.

Dalam menentukan lamanya pidana atau denda, perlu dipertimbangkan mengenai dampak yang ditimbulkanoleh tindak pidana dalam masyarakat serta unsur kesalahan pelaku. ${ }^{7}$ Maka dari itu penjatuhan pidana terhadap pelaku tindak pidana yang melakukan kegiatan usaha pengangkutan bahan bakar minyak tanpa izin usaha pengangkutan harus menunjukkan denganjelas unsur-unsur perbuatan pidana nya. Berdasarkan uraian diatas, maka rumusan masalah yang penulis rumuskan dalam penelitian ini yaitu: Bagaimana pertanggungjawaban pidana terhadap pelaku tindak pidana yang melakukan kegiatan usaha pengangkutan bahan bakar minyak tanpa izin usaha pengangkutan sehingga hakim menjatuhkan pidana?

\section{Tinjauan Pustaka}

Memberikan definisi atau istilah pidana yang sesuai dengan kenyataan tidak semudah yang dibayangkan. Dalam bahasa Belanda istilah pidana disebut dengan "Straf". Istilah pidana tersebut sering diartikan saa mdengan istilah hukuman. Akan tetapi, istilah hukuman itu merupakan istilah umum dan konvesional, serta dapat mempunyai arti yang luas dan berubah-ubah karena istilah itu dapat berkonotasi dengan bidang yang cukup luas. Hal ini disebabkan karena istilah hukuman itu tidak hanya sering digunakan dalam bidang hukum, namun juga dan agama ${ }^{8}$. Istilah pidana merupakan bersifat khusus sehingga perlu ada pembatasan pengertian atau makna sentral yang dapat menunjukkan ciri-ciri atau sifat-sifatnya yang khas 9 .

Pidana merupakan karateristik hukum pidana yang membedakannya dengan hukum perdata. Dalam perkara pidana, seberapa jauh terdakwa telah merugikan masyarakat dan pidana apa yang perlu dijatuhkan kepada terdakwa karena telah melanggar hukum (pidana) ${ }^{10}$.David Garlan menyebutkan bahwa banyak aspek yang perlu dipertimbangkan di

\footnotetext{
${ }^{7}$ H. Syaiful Bakhri, 2012, Hukum Migas, Jakarta, Total Media, hlm. 79.

${ }^{8}$ H. Ishaq, 2020, Hukum Pidana, Depok, Rajawali Pers, hlm. 3.

${ }^{9}$ Ibid, hlm. 3.

${ }^{10}$ Andi Hamzah, 2008, Asas-Asas Hukum Pidana Edisi Revisi 2008, Jakarta, Rineka Cipta, hlm. 27.
} 


\section{PATIK : JURNAL HUKUM Vol : 09 No. 2, Agustus 2020, Hal 137 - 146}

dalam pengertian pidana, sehingga tidak mengherankan bila dijumpai banyak pengertian pidana yang di berikan oleh para ahli hukum ${ }^{11}$.

Menurut Immanuel pidana sebagai sesuatu yang tidakmenyenangkan yang dijatuhkan kepada individu yang melakukan perbuatan terlarang. Dan Menurut Nicola Lacey: pidana adalah sanksi yang dijatuhkan negara tentang apa yang secara umum dipandang sebagai akibat-akibat yang tidak menyenangkan kepada individu atau kelompok yang melanggar hukum, sebagai respons atas pelanggaran tersebut, sebagai bagian dari penegakan hukum, dan respons tersebut tidak hanya dijadikan sebagai sarana untuk menyediakan kompensasi atas kerugian yang ditimbulkan pelaku ${ }^{12}$.

Pidana adalah reaksi atas delik dan ini berujud suatu nestapa yang dengan sengaja ditimpakan negara pada pembuat delik itu, Sudarto memberikan definisi pidana adalah nestapa yang dikenakan oleh negara kepada seseorang yang melakukan pelanggaran terhadap ketentuan undang-undang sengaja agar dirasakan sebagai nestapa ${ }^{13}$. Dalam sistem hukum kita yang menganut asas praduga tak bersalah, pidana sebagai reaksi atas delik yang dijatuhkan harus berdasarkan vonis hakim melalui sidang peradilan atas terbuktinya perbuatan pidana yang dilakukan. Apabila tidak terbukti bersalah maka tersangka harus dibebaskan ${ }^{14}$.

Jadi, secara dogmatis pidana itu ditujukan untuk orang yang normal jiwanya dan mampu bertanggung jawab, sebab orang yang tidak mampu bertanggung jawab tidak mempunyai kesalahan dan orang yang tidak mempunyai kesalahan tidak mungkin dipidana. Sebab, kesalahan adalah adanya keadaan psikis yang tertentu pada orang yang melakukan perbuatan pidana dan adanya hubungan antara keadaan tersebut dengan perbuatan yang dilakukan yang sedemikian rupa sehingga orang itu dapat dicela karena melakukan perbuatan ${ }^{15}$. Untuk pengertian yang sama, sering juga digunakan istilah-istilah yang lain, yaitu salah satunya seperti istilah pemidanaan.Lahirnya pemidanaan bukan muncul begitu saja, melainkan melalui proses peradilan.Pemidanaan merupakan tindakan yang diambil oleh hakim untuk mempidana seorang terdakwa.Pemidanaan adalah cermin dari peradilan pidana bangsa Indonesia.

Pidana harus mengandung semacam kehilangan(deprivation) atau kesengsaraan yang biasanya secara wajar dirumuskan sebagai sasaran dari tindakan pemidanaan. Pemidanaan tidak merupakan konsekuensi alamiah suatu tindakan, melainkan sebagai hasil keputusan pelaku-pelaku personil suatu lembaga yang berkuasa. Karenanya, pemidanaan bukan merupakantindakan balas dendam dari korban terhadap pelanggar hukum yang mengakibatkan penderitaan ${ }^{16}$.

Pidana pada hukum pidana merupakan suatu alat dan bukan tujuan hukum pidana, yang apabila dilaksanakan, tiada lain adalah berupa penderitaan atau rasa tidak enak bagi yang bersangkutan ${ }^{17}$. Masyarakat akan memperoleh keuntungan dan tiada seorang pun yang merugi jika penjahat menjadi baik. Penulis bangsa romawi pada umumnya telah berpendapat bahwa suatu pemidanaan itu haruslah ditujukankepada tiga tujuan seperti tiga pokok pemikiran tentang tujuan yang ingin dicapai dengan suatu pemidanaan, yaitu ${ }^{18}$ untuk memperbaiki pribadi dari penjahat itu sendiri.Untuk membuat orang menjadi jera dalam melakukan kejahatan-kejahatan. Untuk membuat penjahat tertentu menjadi tidak

\footnotetext{
${ }^{11}$ Mahrus Ali, 2017, Asas-Asas Hukum Korporasi, Jakarta, Rajawali Pers, hlm. 231.

${ }^{12}$ Ibid, hlm. 233.

${ }^{13}$ H. Ishaq, Op.Cit., hlm. 3

${ }^{14}$ Bambang Waluyo, 2008, Pidana dan Pemidanaan, Jakarta, Sinar Grafika, hlm. 9.

${ }^{15}$ H. Ishaq, Op.Cit., hlm. 94.

${ }^{16}$ Mahrus Ali, Op.Cit., hal. 233-234.

${ }^{17}$ H. Ishaq, Op.Cit., hal. 4.

${ }^{18}$ P.A.F. Lamintang, Hukum Penintensier Indonesia, Jakarta, Sinar Grafika, 2012, hal. 11.
} 


\section{PATIK : JURNAL HUKUM Vol : 09 No. 2, Agustus 2020, Hal 137 - 146}

mampu melakukan kejahatan yang lain, yakni penjahat yang dengan cara-cara yang lain sudah tidak dapat diperbaiki.

Pidana tidak selamanya didasarkan pada justifikasi moral. Untukmencapaitujuan pemidanaan haruslah di sertai dengan berbagai aliran teori pemidanaan. Teori pemidanaan harus mampu menghadirkan suatu teori moralsistematis untuk menjawab pertanyaan seputar kriminalisasi dan pemidanaanagar mampu menunjukkan bagaimana susatu perbuatanyang secara jelasdianggap terlarang dapat secara moral dibenarkan untuk dilarang ${ }^{19}$.

Dalam Ayat 2 pasal itu dikatakan bahwa pemidanaan tidak dimaksudkan untuk menderitakan dan tidak diperkenankan merendahkan martabat manusia. Dengan demikian dapat dikatakan bahwa yang tercantum di Rancangan KUHP tersebut merupakan penjabaran teori gabungan dalam arti yang luas. Ia meliputi usaha prevensi, koreksi kedamaian dalam masyarakat dan pembebasan rasa bersalah pada terpidana ${ }^{20}$.

Istiah tindak pidana pada hakikatnya merupakan istilah yang berasal dari terjemahan kata "Strafbaar feit" dalam bahasa Belanda, kadang-kadang "Delict" yang berasal dari bahasa Latin "Delictum". Pembentuk undang-undang Indonesia telah menggunakan perkataan Strafbaar feit untuk menyebutkan apa yang dikenal sebagai tindak pidana $^{21}$.Tindak pidana di dalam ilmu hukum pidana merupakan bagian yang paling pokok dan sangat penting. Terdapat perbedaan dari para sarjana hukum pidana mengenai pengertian atau perumusan tindak pidana, namun ada juga persamaannya. Tindak Pidana menunjukkan gerak-gerik tingakah laku dan gerak-gerik jasmani seseorang ${ }^{22}$ Moeljatno mengartikan tindak pidana sebagai perbuatan yang dilarang oleh suatu aturan hukum larangan mana disertai ancaman(sanksi) yang berupa pidana tertentu bagi barangsiapa yang melanggar larangan tersebut. Pada kesempatan lain, beliau juga mengemukakan dengan substansi yang sama bahwa tindak pidana adalah "perbuatan yang dilarang dan diancam dengan pidana, barang siapa melanggar larangan tersebut",23.

A.Z. Abidin mengusulkan pemakaian istilah "perbuatankriminal", karena "perbuatan pidana" yang dipakai olehMoeljatno itu juga kurang tepat, karena dua kata benda bersambungan yaitu "perbuatan" dan "pidana", sedangakan tidak ada hubungan yang logis antara keduanya ${ }^{24}$. Wirjono Prodjodikoro mengartikan bahwa tindak pidana adalah suatu perbuatan yang pelakunya dapat dikenakan hukuman pidana, dan pelaku tersebut dapat dikatakan "subyek" tindak pidana ${ }^{25}$.

Dari beberapa rumusan unsur-unsur tindak pidana yang telah dikemukakan oleh para ahli hukum pidana tersebut di atas, dapat dijelaskan bahwa perihal unsur melawan hukum dan merugikan masyarakat menunjukkan sifat perbuatan yang dilakukan, sedangkan yang disebut pada unsur perbuatan yaitu yang dilarang oleh aturan pidana, pelakunya diancam dengan pidana dan dapat dipertangungjawabkan adalah yang

${ }^{19}$ Mahrus Ali, Op.Cit., hal. 236.

${ }^{13}$ Adami Chazawi, Pelajaran Hukum Pidana Bagian I Stelsel pidana, Tindak Pidana, Teori-Teori Pemidanaan, dan Batas Berlakunya Hukum Pidana, Grafindo Persada, hal 157.

${ }^{20}$ Bambang Waluyo, Op.Cit, hlm. 38.

${ }^{21}$ H. Ishaq, Op.Cit, hlm. 71.

${ }^{17}$ Mahrus Ali, Op.Cit, hlm. 51-52.

${ }^{22}$ Teguh Prasetyo, 2014, Hukum Pidana, Jakarta, Rajawali Pers, hlm. 49

${ }^{24}$ Andi Hamzah, Op.Cit, hlm. 87.

${ }^{19}$ H. Ishaq, Op.Cit, hlm. 76.

${ }^{20}$ Adami Chazawi, , Op.Cit, hlm. 80.

${ }^{21}$ Ibid, hlm. 81.

${ }^{25}$ E.Y. Kanter dan S.R Sianturi, 2002, Asas-Asas Hukum Pidana di Indonesia dan Penerapannya, Jakarta, Storia Grafika, hlm. 209. 


\section{PATIK : JURNAL HUKUM Vol : 09 No. 2, Agustus 2020, Hal 137 - 146}

memastikan bahwa perbuatan itu menjadi suatu perbuatan pidana. Dalam arti kata, suatu perbuatan itu hanya bersifat melawan hukum dan merugikan masyarakat justru belum tentu merupakan suatu perbuatan pidana sebelum dipastikan adanya unsur larangan oleh aturan, pelakunya diancam dengan pidana dan dapat dipertangungjawabkan ${ }^{26}$.

Pidana kurungan pada prinsipnya sama dengan pidana penjara, sama-sama bersifat merampas kemerdekaan bagi si terhukum. Akan tetapi, pidana kurungan lebih ringan daripada pidana penjara. Pidana kurungan maksimum pidananya 1 (satu) tahun dapat dinaikkan menjadi 1 tahun 4 bulan, diancam untuk kejahatan yang tidak disengaja, diperbolehkan untuk mempebaiki nasibnya dengan biaya sendiri dan kerjanya hanya berlangsung selama delapan jam.

Pertanggungjawaban pidana dalam istilah asing disebut denganteorekenbaardheid atau criminal responsibililty yang menjurus kepada pemidanaan pelaku dengan maksud untuk menentukan apakah seorang terdakwa atau tersangka dipertanggungjawabkan atas sesuatu tindakan pidana yang terjadi atau tidak ${ }^{27}$. Dalam hukum pidana konsep liability atau pertanggungjawabanmerupakan konsep sentral yang dikenal dengan ajaran kesalahan. Dalam bahasa Latin ajaran kesalahan ini disebut dengan sebutan "mens rea". Doktrin mens rea dilandaskan pada konsep bahwa suatu perbuatan tidak mengakibatkan seseorang bersalah kecuali jika pikiran orang itu jahat ${ }^{28}$. Kesalahan dalam arti sempit dapat berbentuk sengaja (opzet) atau lalai (culpa). Seorang tersangka/terdakwa dapat dipertanggungjawabkan atas suatu tindak pidana yang dilakukan dan dapat dipidana jika mempunyai kesalahan, yakni apabila pada waktu melakukan perbuatan pidana, dilihat dari segi masyarakat, dia dapat dicela oleh karenanya, sebab dianggap dapat berbuat lain, jika memang tidak ingin berbuat demikian Aspek keslahan (sculd) merupakan asas fundamental dalam hukum pidana dalam menentukan dapat dipidananya pembuat (culpabilitas). Kesalahan diartikan secara luas meliputi kemampuan bertanggungjawab (toerekeningsvaatbaarheid), kesengajaan dan tidak ada alasan pemaaf ${ }^{29}$.

Selain itu, pertanggungjawaban pidana dapat diartikan sebagai diteruskannya celaan yang obyektif yang ada pada tindak pidana dan secara subyektif yang ada memenuhi syarat untuk dapat dipidana karena perbuatannya itu. Dasar adanya tindak pidana adalah asas legalitas, sedangkan dasar dapat dipidananya pembuat adalah asas kesalahan. Pertanggungjawaban pidana pada hakikatnya merupakan suatu mekanisme yang dibangun oleh hukum pidana untuk bereaksi terhadap pelanggaran atas kesepakatan menolak suatu perbuatan. Oleh karena itu, pertanggungjawaban pidana adalah pertanggungjawaban orang terhadap tindak pidana yang dilakukannya ${ }^{30}$.

Istilah minyak bumi berasal dari terjemahan bahasa Ingggris, yaitucrude oil,sedangkan istilah gas bumi berasal dari terjemahan bahasa Inggris, natural gas. Pengertian minyak bumi kita temukan dalam Pasal 3 huruf i The Petroleum Tax Code, 1997 negara India, yang berbunyi sebagai berikut: "Petroleum berarti minyak mentah yang keberadaannya dalam bentuk kondisi alami, seperti semua jenis hidrokarbon, bitumen, keduanya baik dalam bentuk padat dan cair, yang diperoleh dengan cara kondensasi (pengembuanan) atau digali, termasuk di dalamnya dengan cara distilasi (sulingan/saringan) atai kondensasi (pengembuanan) (bilamana berkaitan dengan hidrokarbon yang sangat berat yang direktori sebagai bentuk campuran), tetapi tidak termasuk gas alam. 'Unsur utama minyak dan gas bumi adalah hidrokarbon. Hidrokarbon

\footnotetext{
${ }^{26}$ H. Ishaq, Op.Cit, hlm. 79.

${ }^{27}$ Andi Hamzah, 2010, Asas-Asas Hukum Pidana, Jakarta, Rineka Cipta, hlm. 167.

${ }^{28}$ Mahrus Ali, Op.Cit, hlm. 93.

${ }^{29}$ H. Ishaq, Op.Cit, hlm. 93-95.

${ }^{30}$ Mahrus Ali, Op.Cit, hlm. 94.
} 


\section{PATIK : JURNAL HUKUM Vol : 09 No. 2, Agustus 2020, Hal 137 - 146}

adanya senyawa-senyawa organik di mana setiap molekulnya hanya mempunyai unsur karbon dan hidrogen saja. Karbon adalah unsur bukan logam yang banyak terdapat di alam, sedangkan hidrogen adalah gas tak berwarna, tak berbau, tak ada rasanya, menyesakkan, tetapi tidak bersifat racun, dijumpai di alam dalam senyawa dengan oksigen.

Senyawa hidrokarbonnaften adalah seyawa hidrokarbonjenuh, yang terdapat dalam minyak bumi ialah siklopentan dan sikloheksan. Senyawa hidrokarbon armat adalah senyawa hidrokarbon tidak jenuh, mempunyai sifat kimia yang sangat reaktif, mudah dikosidasi menjadi asam. Senyawa hidrokarbon monoolefin adalah senyawa hidrokarbon yang tidak jenuh dengan sebuah ikatan rangkap dua, dianggap tidak terdapat dalam minyak mentah, tetapi sedikit banyak terbentuk dalam distilasi minyak mentah dan banyak terbentuk dalam proses rengkahan. Sementara itu senyawa hidrokarbon diofelin merupakan senyawa tidak jenuh dengan dua ikatanrangkap dua, tidak terdapat dalam minyak bumi, tidak stabil, sangat reaktif, dan cenderung akan berpolimerisasi dan membentuk damar ${ }^{31}$.

\section{Metode}

Metode pendekatan kasus (case approach) yaitu dengan cara menganalisis kasuskasus yang berkaitan dengan isu yang dihadapi yang telah menjadi putusan pengadilan dan telah mempunyai kekuatan hukum tetap, yakni Putusan Pengadilan Negeri Mempawah Nomor: 569/Pid.Sus/2019/PN.Mpw yaitu dalam Pemidanaan Terhadap Pelaku Yang Melakukan Pengangkutan Bahan Bakar Minyak (BBM) Tanpa Izin Usaha Pengangkutan. Metode pendekatan perundang-undangan (statute approach) yaitu di lakukan dengan cara menelaah peraturan perundang-undangan yang berlaku dalam kasus tersebut Metode penelitian yang di gunakan penulis dalam penelitian penelitian ini adalah metode penelitian kualitatif, yaitu dengan cara meneliti bahan pustaka yang ada. Dalam penelitian ini, bahan hukum primer yang di gunakan adalah peraturan perundang-undangan, yaitu UndangUndang RI Nomor 22 Tahun 2001, tentang Minyak dan Gas Bumi. Adapun bahan hukum sekunder yaitu berupa semua publikasi tentang hukum yang bukan merupakan dokumendokumen resmi yang di gunakan dalam penelitian adalah Putusan Pengadilan Negeri Mempawah Nomor 569/Pid.Sus/2019/PN.Mpw.

\section{Pembahasan Dan Hasil}

Jaksa Penuntut Umum mengajukan RODIANSYAH Bin JEMAIN Ir sebagai Terdakwa pada Pengadilan Negeri Mempawah dalam kasus perkara dengan menyalahgunakan pengangkutan dan/atau niaga Bahan Bakar Minyak yang disubsidi pemerintah berupa solar sebanyak 50 (lima puluh) jerigen yang masing-masing jerigen berisikan 34 (tiga puluh empat) liter dengan jumlah total keseluruhan 1.700 (seribu tujuh ratus) liter solar, dalam pasal 55 UU No. 22 tahun 2001 tentang Minyak dan Gas Bumi dengan dakwaan Tunggal yaitu: Perbuatan Terdakwa tersebut sebagaimana diatur dan diancam pidana dalam Pasal 55 UU No. 22 tahun 2001 tentang Minyak dan Gas Bumi..

1. Menyatakan para Terdakwa RODIANSYAH Bin JEMAINterbukti secara sah dan menyakinkan bersalah melakukan tindak Pidana "MELAKUKAN PENGANGKUTAN BAHAN BAKAR MINYAK (BBM) TANPA IZIN USAHA PENGANGKUTAN"sebagaimana diatur dan diancam pidana dalam Pasal 55 UU No. 22 tahun 2001 tentang Minyak Bumi dan Gas Bumi.

\footnotetext{
${ }^{31}$ H. Salim, Hukum Pertambangan Di Indonesia, Jakarta, Rajawali, 2010, hal. 277-281.
} 
2. Menjatuhkan Hukuman terhadap Terdakwa RODIANSYAH Bin JEMAINdengan pidana penjara selama 3 (tiga) bulan dan denda sebesar Rp.1.000.000,-(satu juta rupiah) subsidiary 1 (satu) bulan kurungan

3. Menetapkan pidana yang dijatuhkan tersebut dikurangkan seluruhnya dari lamanya Terdakwa berada dalam tahanan

4. Menyatakan barang bukti berupa :-1 (satu) Unit Ranmor roda enam jenis Dump Truck Merk HINO warna hijau dengan Nomor Polisi KB 9812 SE, nomor rangka : MJEC1JG43B5027795, nomor mesin : WO4DTRJ-32867, tahun pembuatan 2011, An. Pemilik dalam STNK HIU DJUN BUN -1 (satu) lembar STNK Ranmor roda enam jenis Dump Truck Merk HINO warna hijau dengan Nomor Polisi KB 9812 SE, nomor rangka : MJEC1JG43B5027795, nomor mesin : WO4DTRJ-32867, tahun pembuatan 2011, An. Pemilik dalam STNK HIU DJUN BUN;-1 ( satu ) buah kunci kontak.Dikembalikan kepada saksi KARMIN Bin HASAN (Alm);-50 (lima puluh) jerigen BBM jenis solar yang mana masing -masing jerigen berisi 34 (tiga puluh empat) liter dan jumlah keseluruhan 1700 (seribu tujuh ratus) liter. Dirampas untuk Negara

5. Menetapkan agar terdakwa membayar biaya perkara sebesar Rp.2000,(dua ribu rupiah)

Surat dakwaan adalah surat yang berisi dakwaan bahwa seseorang telah melakukan tindak pidana. Surat dakwaan pada hakekatnya adalah kesimpulan Jaksa Penuntut Umum tentang apa yang dilakukan oleh tersagka berdasarkan hasil penyidikan dan dasar bagi penuntut umum dalam mengajukan terdakwa ke pengadilan. Surat dakwaan adalah dasar bagi pemeriksa perkara selanjutnya, baik pemeriksaan di persidangan pengadilan negeri, pemeriksaan di tingkat banding, kasasi. Artinya, Jaksa hanya bisa menuntut terdakwa tidak boleh lebih dari ancaman yang dikenakan dalam Pasal surat dakwaan.

Bahwa berdasarkan posisi kasus sebagaimana dalam putusan Nomor : 569/Pid.Sus/2019/PN.Mpw telah diuraikan dalam surat dakwaan yang diajukan oleh Jaksa Penuntut Umum pada PN Mempawah yang memeriksa dan mengadili perkara pada tingkat pertama. Hal ini dimuat dalam surat dakwaan Jaksa Penuntut Umum pada Putusan Nomor : 569/Pid.Sus/2019/PN.Mpw adalah dakwaan Tunggal. Dalam dakwaanya Jaksa Penuntut umum menggunakan dakwaan yang berbentuk tunggal. Maksudnya adaiah dakwaan iniDalam surat dakwaan ini hanya satu tindak pidana saja yang didakwakan. Tidak terdapat dakwaan lain sebagai alternatif dan kumulatif. Terdakwa diajukan di depan persidangan oleh Jaksa Penuntut Umum dengan menggunakan dakwaan tunggal sebagai berikut: Perbuatan Terdakwa tersebut sebagaimana diatur dan diancam pidana dalam Pasal 55 UU No. 22 tahun 2001 tentang Minyak dan Gas Bumi.

Oleh karena itu, penulis sependapat dengan Jaksa Penuntut Umum, dimana tindakan Jaksa Penuntut Umum dalam memberikan dakwaan tunggal sudah tepat, dikarenakan adanya kemiripan unsur di antara beberapa Pasal yang berkaitan dengan tindak pidana pengangkutan tanpa izin pengangkutan orang agar si terdakwa tidak terlepas dari tuntutan hukum. Di dalam Pasal 1 ayat 7 KUHAP dicantumkan pengertian penuntutan. Penuntutan adalah tindakan penuntut umum untuk melimpahkan perkara pidana ke Pengadilan Negeri yang berwenang dalam hal dan menurut cara yang diatur dalam undang-undang ini dengan permintaan supaya diperiksa dan diputus oleh majelis hakim di sidang pengadilan.

Pada uraian diatas tentang tuntutan jaksa penuntut umum terhadap terdakwa penulis sependapat hal ini dalam pandangan penulis menilai dari tujuan hukum yaitu dari segi kemanfaatannya. Dalam hal ini sebagaimana dalam posisi perbuatan terdakwa 


\section{PATIK : JURNAL HUKUM Vol : 09 No. 2, Agustus 2020, Hal 137 - 146}

mengangkut minyak tanpa izin namun dalam hal ini benar adanya tindakan penuntut umum tidak menuntut maksimal penjara terhadap terdakwa. Penulis menilai aspek kepastian telah tercapai maka seharusnya tujuan pemidanaan juga telah tercapai dalam tuntutan ini dimana jaksa menuntut memperhatikan hak-hak dari terdakwa maka dalam hal ini seharusnya keadilan itu sendiri juga telah tercapai.

Pada kasus tersebut diatas, dikaitkan dengan fakta-fakta yang terdapat pada barang bukti, keterangan saksi, keterangan terdakwa yaitu sdr. RODIANSYAH Bin Jemain terbukti melanggar Pasal 55 Undang-Undang R.I Nomor 22 Tahun 2001 Tentang Minyak dan Gas Bumi. Penerapan hukum pidana dalam perkara Nomor: 569/PID.SUS/2019/PN.MPW adalah berdasarkan hasil penelitian, penulis menganggap telah terpenuhi unsur-unsur dalam Pasal 55 Undang-Undang R.I Nomor 22 Tahun 2001 Tentang Minyak dan Gas Bumi. Dalam menjatuhkan putusan, hakim berdasarkan pada keterangan saksi dan keterangan terdakwa, dan berdasarkan fakta yang terungkap dipersidangan, hakim beranggapan bahwa terdakwa bersalah melakukan tindak pidana pengangkutan bahan bakar minyak tanpa izin usaha pengangkutan.

\section{Kesimpulan dan Saran}

Pada kasus tersebut diatas, dikaitkan dengan fakta-fakta yang terdapat pada barang bukti, keterangan saksi, keterangan terdakwa yaitu sdr. RODIANSYAH Bin Jemain terbukti melanggar Pasal 55 Undang-Undang R.I Nomor 22 Tahun 2001 Tentang Minyak dan Gas Bumi. Penerapan hukum pidana dalam perkara Nomor: 569/PID.SUS/2019/PN.MPW adalah berdasarkan hasil penelitian, penulis menganggap telah terpenuhi unsur-unsur dalam Pasal 55 Undang-Undang R.I Nomor 22 Tahun 2001 Tentang Minyak dan Gas Bumi. Dalam menjatuhkan putusan, hakim berdasarkan pada keterangan saksi dan keterangan terdakwa, dan berdasarkan fakta yang terungkap dipersidangan, hakim beranggapan bahwa terdakwa bersalah melakukan tindak pidana pengangkutan bahan bakar minyak tanpa izin usaha pengangkutan. Hendaknya pengaturan dalam Undang-Undang R.I Nomor 22 Tahun 2001 Tentang Minyak dan Gas Bumi dalam jumlah bahan bakar minyak yang diangkut dapat diperluas lagi serta kiranya pemerintah daerah dapat mensosialisasikan bagaimana cara mendaftarkan izin usaha pengangkutan bahan bakar minyak dan dampak dari melakukan kegiatan ini agar kiranya kejadian ini tidak terulang kembali.

\section{DAFTAR PUSTAKA}

\section{Buku dan Jurnal}

Abidin Farid Zainal, 2007, Hukum Pidana 1, Sinar Grafika, Jakarta.

Jenik, Ivo dan Kate Lawer. 2017. Regulatory Sandboxes and Financial Inclusion. Washington D.C: CGAP

Dirjosisworo Soedjono.1990. Hukum Narkotika di Indonesia. Bandung .PT. citra Aditya bakti..

Hermawan S. Rachman 1987. Penyalahgunaan Narkotika Oleh Para Remaja. Bandung. Penerbit Eresco.

Hamzah Andi, Asas-Asas Hukum Pidana, Rineka Cipta, Jakarta, 1991,

Huda Choerul, Dari Tiada Pidana Tanpa Kesalahan Menuju Kepada Tiada Pertanggungjawaban Pidana tanpa Kesalahan, Kencana,Jakarta, 2006, 
PATIK : JURNAL HUKUM Vol : 09 No. 2, Agustus 2020, Hal 137 - 146

Ira Thania Rasjidi dan H. Lili rasjidi "Dasar-Dasar Filsafat dan Teori Hukum" PT. Citra Aditya Bakti, cetkan ke-11, Bandung

Lamintang, 1984, Hukum Penitersier Indonesia. Alumni, Bandung

Makarro Moh, Taufik, Suhasril,.Zakky H.Moh "Tindak Pidana Narkotika" Ghalia Indonesia" Jakarta 2003

Marpaung Leden, Asas-Teori-Praktik Hukum Pidana, Sinar Grafika,. Jakarta, 2005

M. Sholehuddin, Sistem Sanksi dalam Hukum Pidana: Ide Dasar Doble Track System \& Implementasinya, Rajawali Pers, Jakarta, 2004

Muladi. Lembaga Pidana Bersyarat, P.T. Alumni. Bandung, 2004,

Setiady Tolib, Pokok-Pokok Hukum Penitensier Indonesia, Bandung, Alfabeta, 2010,

Poeromo Bambang 1994, "Asas-asas Hukum Pidana" Ghalia Indonesia terbitan ke-7 Yogyakarta

Prodjodikoro Wirjono, Hukum Acara Pidana di Indonesia, Sumur Bandung, Bandung, 1981

Prakoso Djoko, Surat Dakwaan, Tuntutan Pidana dan Eksaminasi Perkara di Dalam Proses Pidana, Liberty, Yogyakarta

Ridwan Zachrie dan Wijayanto, Korupsi Mengorupsi Indonesia, PT Gramedia Pustaka Utama, Jakarta,2009

Simamora, Janpatar., Tafsir Makna Negara Hukum dalam Perspektif Undang-Undang Dasar Negara Republik Indonesia Tahun 1945, Jurnal Dinamika Hukum FH Universitas Jenderal Soedirman, Vol. 14 No. 3 September 2014.

Sudarto. Hukum dan Hukum Pidana. Alumni. Bandung, 1997

Supramono, G. 2001. Hukum Narkotika Indonesia.Djambatan, Jakarta.

Soekanto Soerjono, 2002, "Pokok-Pokok Sosilologi Hukum" PT.Raja Grafindo Persada,cetakan ke-12, Jakarta

Waluyo Bambang, "Penelitian Hukum dalam Praktek" Sinar Grafika, cetakan ke-4, Jakarta 